\title{
Минский процесс: общественное восприятие и нарративы
}

\author{
Сесиль Дрюэ, Анна Хесс, Юлия Каплан, Валентина Череватенко*
}

\section{Аннотация}

Официальный переговорный процесс по урегулированию конфликта на востоке Украины «Минский процесс» - продолжается с 2014 года, но практически не принес ощутимых результатов. На основе интервью, проведенных с людьми, проживающими в разных регионах Украины и России, в данной публикации анализируется отношение к «Минскому процессу» тех, кто больше всего пострадал от конфликта. Исходя из того, что ключевым вопросом конфликта является восстановление украинской государственности в неподконтрольных правительству районах Донецкой и Луганской областей, в статье выделены два основных подхода к урегулированию: «сначала граница» или «сначала статус». Изучение потребностей и опасений, которые определяют отношение в обществе к этим подходам, позволяет выявить общие интересы и определить пространство для принятия взаимоприемлемых решений.

\section{Ключевые слова}

Конфликт в Украине, Донбасс, Минский процесс, общественное восприятие, расходящиеся позиции, общие интересы

Для цитирования этой публикации: Дрюэ С., Хесс А., Каплан Ю., Череватенко В. Минский процесс: общественное восприятие и нарративы // ОБСЕ Insights 8. - Баден-Баден: Номос, 2021. URL: https://doi.org/10.5771/9783748921264-08

* Сесиль Дрюэ, доктор наук, Бернский университет, Швейцария, cecile.druey@hist.unibe.ch Анна Хесс, Центр изучения проблем безопасности, Швейцарская высшая техническая школа Цюриха, Швейцария

Юлия Каплан, кандидат наук, Национальный институт стратегических исследований (НИСИ), Украина

Валентина Череватенко, кандидат наук, Председатель-координатор РОПО Союз «Женщины Дона», Россия 


\section{Введение 251}

На протяжении последних шести лет официальный процесс урегулирования конфликта на Донбассе на востоке Украины, известный как «Минский процесс», был направлен на реализацию положений так называемых Минских договоренностей, призванных восстановить мир и безопасность на востоке Украины. Этой цели так и не удалось достичь. В основе проблемы лежит тот факт, что противоположные позиции по ключевым положениям договоренностей, касающимся, к примеру, восстановления украинской государственности на востоке Украины, занимают не только участвующие в минских переговорах официальные лица. Эти различия проявляются и на общественном уровне во всех пострадавших от конфликта районах.

Целью данной статьи является прояснение существующих в обществе подходов к урегулированию и анализ стоящих за ними интересов, потребностей и опасений. Мы не ищем ответ на вопрос, кто несет ответственность за войну или какие политические подходы в наибольшей степени способствуют ее прекращению. Мы видим свою задачу в исследовании того, как официальный мирный процесс и его ключевые положения воспринимаются обществами каждой из сторон, а также в попытке выявить те общие интересы, на основе которых можно было бы разблокировать путь к устойчивому миру.

Работа основана на исследовании «Минский процесс - взгляд изнутри», которое было концептуально разработано и осуществлено украинскими, российскими и швейцарскими исследователями ${ }^{252}$ в 2017-2020 гг. в рамках международной диалоговой платформы «Женские инициативы за мир на Донбассе» (ЖИМД) ${ }^{253}$. В исследовании рассматривалось восприятие «Минского процесса» в различных регионах Украины, в том числе в районах Донецкой и Луганской областей, которые не контролируются украинским правительством, и в России ${ }^{254}$. В соответствии с подходом ЖИМД, сочетающим диалог и практическое сотрудничество, иногда называемым «диапрактикой» ${ }^{255}$, проект был реализован в форме исследовательского диалога, peзультаты которого были получены в процессе постоянного обмена между исследователями, представляющими различные стороны конфликта.

Первоначальная цель исследования заключалась в том, чтобы дополнить повестку дня официальных переговоров теми вопросами, которые возникают в обществе в связи с «Минским процессом», исходя из того, что исключение представителей общества из переговоров может привести к появлению в будущих договоренностях «слепых зон» и создать проблемы для их реализации. Наши предварительные выводы опровергли это предположение. Они показали, что восприятие обществом ключевых положений Минских договоренностей, хотя оно и исключено из официального дискурса, в целом отражает различия в позициях, которые привели к тупику на переговорах. Этот вывод побудил нас пересмотреть цели исследования, и мы постарались проанализировать лежащие в основе восприятия обществом «Минского процесса» интересы, чтобы выявить области, в которых они совпадают. Такой анализ 
позволил бы сформулировать потенциально взаимоприемлемые варианты урегулирования, полезные не только для официального мирного процесса, но и для многоуровневых миротворческих инициатив.

В данной работе мы сосредоточимся на одном из ключевых вопросов «Минского процесса», который также оказался одним из самых спорных для опрошенных в ходе нашего исследования респондентов: восстановление украинской государственности на востоке страны. Для этого мы выделили два основных нарратива, которые мы назвали «сначала граница» и «сначала статус». Изучение интересов, лежащих в основе этих противоположных нарративов, выявило ряд опасений и потребностей, разделяемых респондентами, представляющими разные стороны. Наиболее значимые опасения и потребности, особенно для респондентов из районов, находящихся в непосредственной близости от зоны конфликта, связаны с такими вопросами, как демилитаризация и физическая безопасность, социально-экономическое выживание и мобильность, а также участие в политической жизни. Наш анализ показывает, что между умеренными позициями в рамках двух основных нарративов существует потенциальное пространство для поиска взаимоприемлемых решений.

\section{Методология}

В нашем исследовании позиции и интересы опрошенных рассматривались исходя из концептуального подхода, сформулированного гарвардской школой ведения переговоров, в которой основное внимание уделяется удовлетворению интересов. Ключевой принцип гарвардского метода заключается в необходимости проводить различие между конкретными позициями, которые занимают участники переговоров, и лежащими в их основе интересами. Соответственно, понимание интересов, потребностей и опасений сторон повышает шансы на разработку вариантов, способствующих достижению взаимоприемлемого решения ${ }^{256}$.

Данные были собраны на основе 144 качественных интервью, проведенных в 2018-2019 гг. и охватывающих все географические регионы, затронутые конфликтом на Донбассе. К ним относятся контролируемые правительством районы Украины (в центральной, западной, восточной и южной частях страны), неподконтрольные властям районы (в Луганской и Донецкой областях) и Россия (приграничные с Украиной регионы, а также регионы в центральной части России). Интервью были проведены также с внутренне перемещенными лицами из Донбасса в Украине и донбасскими беженцами в России. Последняя группа оказалась ценным источником, поскольку позиции, занимаемые донбасскими беженцами в России, часто более открыто отражают мнения жителей неподконтрольных правительству районов. Исследование не преследовало цель сбора количественной информации или оценки пропорций представленности тех или иных позиций. Оно было сосредоточено на анализе нарративов, которые были сформулированы на основе тематически закоди- 
рованных интервью и сопоставлены с данными о географическом и демографическом распределении групп респондентов. Исследование не было направлено на какую-либо конкретную социальную группу и основывалось на добровольном участии. Возможно, в результате такого отбора, основанного на мотивации, около двух третей респондентов имели высшее образование. Большинство из них были в возрасте от 35 до 55 лет, а женщины были представлены в несколько большей мере, чем мужчины (57\%).

\section{Общий фон}

С момента возникновения в 2014 году конфликт на востоке Украины унес более 13 000 жизней 257 . В настоящее время в Украине проживает около 1,5 миллиона внутренне перемещенных лиц ${ }^{258}$, и по меньшей мере один миллион беженцев покинули Донбасс и уехали в Россию ${ }^{259}$. В результате конфликта высокой интенсивности Украина потеряла контроль над государственной границей с Россией и частью Донбасса - самопровозглашенными Донецкой и Луганской Народными Республиками ${ }^{260}$. 472-километровая линия соприкосновения делит регион на контролируемые и не контролируемые правительством районы ${ }^{261}$. Конфликт не только нарушил государственный суверенитет Украины, но и нанес серьезный ущерб инфраструктуре, подорвал экономику и привел к тяжелым гуманитарным последствиям для пострадавшего населения. Ситуация с безопасностью на линии соприкосновения остается нестабильной. Линии разлома не совпадают с географическими и идеологическим границами, а проходят прямо через сердце общества, когда члены семьи и друзья часто оказываются в разных лагерях.

Международные усилия по урегулированию конфликта на востоке Украины были начаты в 2014 году, но насилие не ослабевало до конца 2016 - начала 2017 года. То, что обычно называют Минскими договоренностями - это три документа, согласованные в сентябре 2014 (Минский протокол и Минский меморандум) и феврале 2015 года (Комплекс мер по выполнению Минских договоренностей), подписанные Россией, Украиной и представителями неподконтрольных властям районов под эгидой глав четырех государств и правительств в «нормандском формате» (Германия, Франция, Россия и Украина). Эти договоренности служат основой для переговоров в рамках Трехсторонней контактной группы (ТКГ) ОБСЕ и ее четырех тематических рабочих групп ${ }^{262}$. «Минский процесс» и, в частности, ТКГ являются единственным форматом, в котором официально участвуют все стороны конфликта. Однако за шесть лет, прошедших после подписания договоренностей, в результате проходящих в Минске раз в две недели встреч не были достигнуты ни всеобъемлющее и устойчивое прекращение огня, ни политическое урегулирование. Одним из ключевых препятствий на пути реализации минских договоренностей остается вопрос о последовательности выполнения их политических положений и положений, 
касающихся безопасности. К другим факторам, препятствующим их выполнению, относятся процедурная непрозрачность и оспариваемая политическая и военная роль России.

\section{Восстановление украинской государственности: от противоположных позиций к совпадающим интересам?}

Как упоминалось выше, восстановление украинской государственности на востоке страны является основным предметом разногласий в рамках «Минского процесса». В то время как украинское правительство настаивает на восстановлении контроля над своей границей с Россией до принятия каких-либо решений о статусе не контролируемых им районов, последние при поддержке России требуют автономии и гарантий безопасности прежде чем обсуждать возможную реинтеграцию с Украиной. На первый взгляд, расхождения в нарративах, выявленные в нашем исследовании, а именно между подходами «сначала граница» и «сначала статус», отражают официальные позиции, которые привели к нынешнему тупику. Однако наш анализ показывает, что респонденты придерживаются широкого спектра позиций. Между крайностями «жесткой реинтеграции» и «полной независимости» можно выявить более умеренные подходы, на основе которых можно сформулировать взаимоприемлемые решения.

Спектр высказываемых позиций резюмируется в следующих подразделах, за которыми следует краткое изложение стоящих за ними страхов и потребностей, а также реакций, которые они спровоцировали. В таблице 1 представлен их обзор. 


\section{Таблица 1: Обзор нарративов и позищий}

\begin{tabular}{|c|c|c|c|}
\hline Нарратив & Позиция & $\begin{array}{c}\text { Лежащие в основе страхи и } \\
\text { интересы }\end{array}$ & $\begin{array}{c}\text { Разделяется } \\
\text { (группа респондентов) }\end{array}$ \\
\hline \multirow{3}{*}{$\begin{array}{l}\text { Нарратив } 1 . \\
\text { «Сначала грани- } \\
\text { ца»: } \\
\text { в первую очередь } \\
\text { требуется восста- } \\
\text { новление контроля } \\
\text { Украины }\end{array}$} & $\begin{array}{l}\text { Позиция } 1 \\
\text { «Жесткая реинтегра- } \\
\text { ция и восстановление } \\
\text { статус-кво анте» }\end{array}$ & $\begin{array}{l}\text { Страх: } \\
\text { • } \quad \text { ползучая русификация } \\
\text { Украины } \\
\text { Интерес: } \\
\text { • } \\
\text { статус-кво анте } \\
\text { (Украина, включающая } \\
\text { Донбасс и Крым) }\end{array}$ & $\begin{array}{ll}\text { - } & \text { Украина } \\
& \text { (в основном южная и цен- } \\
\text { тральная части) } \\
\text { • } \\
\text { Россия } \\
\text { (центральная часть) }\end{array}$ \\
\hline & $\begin{array}{l}\text { Позиция 2: } \\
\text { «Территориальная } \\
\text { целостность } \\
\text { и национальные ин- } \\
\text { тересы» }\end{array}$ & $\begin{array}{l}\text { Страх: } \\
\begin{array}{l}\text { - } \quad \text { особый статус неконтроли- } \\
\text { руемых районов как угроза } \\
\text { украинскому государству } \\
\text { (территориальная раздроб- } \\
\text { ленность) }\end{array}\end{array}$ & $\begin{array}{ll}\text { - } & \text { Украина (все регионы) } \\
\text { - } & \text { Россия (все части) }\end{array}$ \\
\hline & $\begin{array}{l}\text { Позиция 3: } \\
\text { «Мягкая реинтегра- } \\
\text { ция } \\
\text { и восстановление го- } \\
\text { сударственности» }\end{array}$ & $\begin{array}{l}\text { Интересы: } \\
\text { • } \quad \text { социально-экономическое } \\
\text { выживание } \\
\text { • } \\
\text { восстановление государ- } \\
\text { ственности и инфраструк- } \\
\text { туры в регионе конфликта }\end{array}$ & $\begin{array}{ll} & \text { Украина - районы, близ- } \\
\text { кие к зоне конфликта (кон- } \\
\text { тролируемые и не контро- } \\
\text { лируемые правительством) } \\
\text { • } \\
\text { Россия - (приграничный } \\
\text { регион) }\end{array}$ \\
\hline \multirow{2}{*}{$\begin{array}{l}\text { Нарратив } 2 . \\
\text { «сначала статус» } \\
\text { в первую очередь } \\
\text { требуется особый } \\
\text { статус - автоно- } \\
\text { мия - независи- } \\
\text { мость для непод- } \\
\text { контрольных тер- } \\
\text { риторий }\end{array}$} & $\begin{array}{l}\text { Позиция 4: } \\
\text { «Независимость или } \\
\text { объединение с Росси- } \\
\text { ей» }\end{array}$ & $\begin{array}{l}\text { Страх: } \\
\text { • } \quad \text { изоляция } \\
\text { • } \quad \text { «жесткая интеграция» как } \\
\text { гуманитарная катастрофа } \\
\text { для жителей неподкон- } \\
\text { трольных районов } \\
\text { Интерес: } \\
\text { • гуманитарная безопасность } \\
\text { неподконтрольных районов }\end{array}$ & $\begin{array}{ll}\text { - } & \text { неподконтрольные районы } \\
\text { - } & \text { донбасские беженцы в } \\
\text { России }\end{array}$ \\
\hline & $\begin{array}{l}\text { Позиция 5: } \\
\text { «Временная автоно- } \\
\text { мия и мягкая незави- } \\
\text { симость» }\end{array}$ & 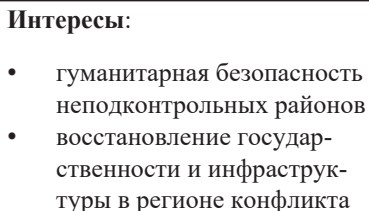 & $\begin{array}{ll} & \text { подконтрольные регионы } \\
\text { Украины (все части) } \\
\text { неподконтрольные районы } \\
\text { • } \\
\text { Россия (приграничный ре- } \\
\text { гион) }\end{array}$ \\
\hline
\end{tabular}




\section{Нарратив I: Реинтеграция и позиция «сначала граница»}

Противоречие между двумя основными нарративами - «сначала граница» и «сначала статус» - зеркально отражает проблему последовательности реализации положений Минских договоренностей, касающихся вопросов безопасности и политических аспектов урегулирования. Респонденты, придерживающиеся принципа «сначала граница», полагают, что прежде чем будут предприняты дальнейшие шаги по урегулированию Украина должна восстановить контроль над границей с Россией.

Позиция 1: «Жесткая реинтеграция и восстановление статус-кво анте» «Я не сторонница особых статусов для этих [неподконтрольных] регионов, кроме той особости, что в этих регионах долюна быть суровая дисииплина, наблюдение, строгий режим. Короче, я хочу и считаю это справедливыл и правильныл, чтоб эти регионы были наказаны». (Центральная Украина)

Среди более радикальных подходов в рамках нарратива «сначала граница» - призыв к «жесткой реинтеграции» неподконтрольных районов в состав Украины. Он часто сочетается с призывом к восстановлению территориального «статус-кво анте» (включая Крым). В военном отношении сторонники «жесткой реинтеграции» понимают ее как восстановление полного контроля над границей с Россией (и ее полное закрытие) и военный захват Донбасса. С социально-культурной точки зрения это означало бы восстановление полного контроля и новую украинизацию населения неподконтрольных районов, часто сочетающихся со стремлением к возмездию (см. цитату выше). Предоставление неподконтрольным районам автономии на основании закона об особом статусе, как это предусмотрено в Минских договоренностях, категорически отвергается этими респондентами, опасающимися того, что «особый статус» даст России возможность оказывать давление на Киев в процессе принятия им решений по вопросам внешней политики и политики безопасности, используя для этого участие донбасских властей в украинской политике 263 . В целом сторонники данной позиции считают российскую агрессию главной, если не единственной причиной конфликта на Донбассе, понимая популярный лозунг «Россия вон!» как путь к спасению, а де-русификацию Донбасса как необходимое условие для установления мира. Интересно, что поддержка идеи «жесткой реинтеграции» и требования «Россия - вон!» была высказана респондентами не только на юге и в центре Украины, но и в России, чаще всего в регионах, наиболее удаленных от зоны непосредственного конфликта.

Идею «жесткой реинтеграции» с ее предпочтением военного решения и идеологическим и высокоэмоциональным накалом не разделяют в первую очередь жители неподконтрольных правительству Украины районов и донбасские беженцы в России. С ней также не соглашаются респонденты, живущие вблизи зоны конфликта в контролируемых правительством районах Донбасса и на юге России. Они утвержда- 
ют, что силовой захват Донбасса поставит под угрозу безопасность и экономическое развитие всего региона.

Радикальная поддержка «жесткой реинтеграции», по-видимому, отчасти объясняется отсутствием достоверной информации о содержании и ходе переговоров в рамках «Минского процесса». Несколько респондентов из числа жителей подконтрольных и неподконтрольных правительству районов, а также из числа донбасских беженцев в России отметили, что у них мало или вообще нет информации о переговорном процессе, а та информация, которую они получают, как правило, поступает из неформальных источников. Их доверительными источниками являются блогеры и влиятельные представители элиты. Однако неверное использование таких терминов как «особый статус», «федерализм», «автономия» и «амнистия» поддерживает формирование мифов о ползучих кормах русификации. В результате недостаточная прозрачность и нехватка достоверной информации о том, что конкретно означают эти ключевые понятия, привели к распространению страхов и ужесточению позиций.

Позиция 2: «Территориальная целостность и национальные интересы»

«[Восстановление мира означает] полный контроль Украины над всей государственной границей Украины, я считаю, абсолютно необходимыли, ну, для любой страны, ее суверенным правом!» (Центральная Украина)

Данный подход также вписывается в нарратив «сначала граница», но в его рамках вопрос о реинтеграции рассматривается с правовой и институциональной, а не идеологической точки зрения. Сторонники данного подхода полагают, что неподконтрольные правительству районы должны быть реинтегрированы, а пограничный контроль - восстановлен, исходя из права (и обязанности) украинского государства осуществлять юрисдикцию на всей ее международно-признанной территории.

Такой подход отличается от «жесткой реинтеграции» не только своей большей трезвостью, но и тем, что он вызывает меньше возражений. Среди респондентов из всех групп, включая жителей неподконтрольных правительству Украины территорий и еще более радикальных беженцев на юге России, существует широкий консенсус относительно целесообразности обеспечения территориальной целостности Украины и действенного контроля на границе с Россией, поскольку это - важные условия для нормального функционирования украинского государства.

Когда мы глубже рассмотрели подход «территориальная целостность и национальные интересы» и более радикальный подход «жесткая реинтеграции» и «Россия - вон!», то стало ясно, что главный интерес, лежащий в основе обеих позиций, необходимость обеспечения суверенитета Украины и страх перед перспективой ее дальнейшей территориальной раздробленности. Боязнь фрагментации украинской государственности идет рука об руку с негодованием по поводу возможного в этом случае доминирования России. Призыв к полному выводу российских сил, нежелание договориться о порядке проведения местных выборов и предоставлении непод- 
контрольным районам особого статуса также подогреваются опасением русификации восточной Украины. Некоторые респонденты на юге России и в контролируемом Украиной Донбассе выразили опасения по поводу геополитизации конфликта, в частности, использования Москвой Донбасса и проницаемости его границы с Россией в качестве инструментов, позволяющих то замораживать, то размораживать конфликт в зависимости от позиции Киева по отношению к Москве.

Позиция 3: «Мягкая реинтеграция и восстановление государственности» "[Украинский контроль на государственной гранище означает] контроль въезда-выезда граждан и нерезидентов страны. Точно так же, как и с экономической точки зрения движения товаров. Но этот пункт там [т.е. в Минских договоренностях] прописан исключительно для того, чтобы, ну, официильно как бы не пропускать вооруженное подкрепление для вооруженных...» (Восточная Украина - подконтрольные районь Донбасса)

Среди более умеренных подходов в рамках нарратива «сначала граница» - «мягкая реинтеграция». В отличие от более жестких подходов, о которых говорилось выше, в нем акцентируется не контроль или закрытие границы, а необходимость восстановления границ, которые выполняли бы свои нормальные функции, в рамках восстановления и консолидации украинской государственности в районах, непосредственно затронутых конфликтом.

Данная позиция согласуется с концепцией «позитивного мира» Йохана Галтунга, в которой стабильность понимается шире, чем в военном плане, и которая предполагает необходимость решения не только вопросов обеспечения (физической) безопасности, но и более глубоких проблем, приведших к конфликту ${ }^{264}$. В частности, респонденты из районов, близких к зоне конфликта на подконтрольных Украине территориях и на юге России, подчеркивали важность «позитивного» государственного присутствия как основы для успешной реинтеграции в будущем. По их мнению, это подразумевает восстановление правовой системы, социально-экономической инфраструктуры, а также наличие функционирующих органов государственного и местного управления во всей Украине, включая неподконтрольные властям районы. С этой точки зрения, восстановление Украиной контроля над границей влечет за собой контроль не только за оружием, но и за перемещением людей и товаров. Такая точка зрения особенно распространена среди респондентов из районов, близких к зоне конфликта (контролируемые украинским правительством районы Донбасса, неподконтрольные районы и юг России). Для них важно, чтобы и российско-украинская граница, и внутренняя украинская линия соприкосновения были безопасными и благоприятствовали мобильности с обеих сторон. 


\section{Общие интересы: Социально-экономическое выживание и мобильность}

Потребности, лежащие в основе подходов, предполагающих восстановление государственности и реализацию принципа «сначала граница», связаны с необходимостью обеспечения безопасности, социально-экономического выживания, мобильности и достойного образа жизни. Большое количество респондентов на неподконтрольных территориях также заинтересовано в «позитивном» мире и решении проблемы реинтеграции на основе учета интересов людей. Они терпимо восприняли или даже поддержали идею реинтеграции при условии удовлетворения их потребностей в обеспечении безопасности и социально-экономических потребностей.

Восстановление «позитивного» присутствия украинского государства на всей территории Донбасса можно идентифицировать как вторую область совпадающих интересов респондентов из разных групп по обе стороны границы и линии соприкосновения, что может открыть возможности для компромисса.

\section{Нарратив II: Автономия и «сначала статус»}

Респонденты, поддержавшие второй нарратив, который мы назвали «сначала статус», рассматривают предоставление неподконтрольным районам особого статуса (независимость, автономия или федерализация) до проведения выборов в местные органы власти как ключевой приоритет. Решение данного вопроса должно предшествовать восстановлению пограничного контроля и подготовить почву для дальнейших шагов на пути к миру. Подобно подходу «сначала граница», в рамках данного нарратива также существуют разные подходы к решению задач потенциального восстановления украинской государственности. В то время как одни сторонники подхода «сначала статус» настаивают на «независимости любой ценой» для неподконтрольных властям районов, другие рекомендуют предоставить особый статус Луганску и Донецку в качестве временного решения на пути к более комплексному урегулированию. Умеренные позиции и в этом случае предполагают возможности для поиска взаимоприемлемых решений.

Позиция 4: «Независимость или объединение с Россией»

"[Слово] «Украина» ассочиируется как смерть с косой. То есть, это [m.е. переговоры] полностью замкнутое кольијо. Делай, что хочешь, а рассказывай по радио и телевизору все, что ты другое захочешь. Можно мило ульбаться и при этом душить свой народ...» (Российская Федерация, донбасские беженцьь)

Как видно из приведенной выше цитаты, сторонники идеи «независимости любой ценой» воспринимают перспективу реинтеграции и восстановления Киевом контро- 
ля над границей с Россией как непосредственную угрозу своей безопасности. Заявления некоторых жителей неподконтрольных властям районов и большинства опрошенных в ходе исследования донбасских беженцев в России высказывают точку зрения, согласно которой «война стала точкой невозврата». Они полагают, что в результате войны и шестилетнего отчуждения единственным вариантом для неподконтрольных властям районов является максимальная независимость от центральных властей в Киеве или вхождение в состав России в случае, если независимости будут препятствовать.

Подобно радикальным подходам в рамках нарратива «сначала граница» сторонники «независимости любой ценой» отводят центральную роль России. Распространенное восприятие России как гаранта мира и бескорыстного защитника местного населения превращает вариант потенциального объединения неподконтрольных правительству районов с Россией в привлекательную альтернативу воссоединению с Украиной, особенно если последнее предполагало бы «жесткую реинтеграцию».

Требование «независимости любой ценой» понимается как способ удовлетворения потребности сторон в физической безопасности и обеспечении безопасности человека в более широком смысле. Проницаемость границы с Россией оказалась жизненно важной для жителей неподконтрольных районов во время интенсивных военных действий и последующей изоляции от Украины. Эти респонденты опасаются, что без решения вопроса о политическом статусе и в отсутствие гарантий безопасности Донбасса со стороны Киева они окажутся в замкнутом пространстве между закрытой границей с Россией и режимом ограниченного доступа на линии соприкосновения.

Призыв к полной независимости продиктован не только соображениями жесткой безопасности, но и социально-психологическими соображениями. В частности, жители неподконтрольных районов и донбасские беженцы в России опасаются «возмездия» со стороны Украины в случае их реинтеграции. Этот страх усугубляется социально-психологическими последствиями вооруженного конфликта и шестилетним отчуждением неподконтрольных районов от других районов Украины. Война, столкновения со смертью, разрушениями и перемещениями стали причиной глубоких психологический травм. Донбасские беженцы в России особенно опасаются возобновления конфликта в случае восстановления полного контроля Украины над восточными районами. Многие жители неподконтрольных районов опасаются того, что в результате реинтеграции в Украине к ним будут относиться как к «гражданам второго сорта» из-за культурных и языковых различий, которые проявляются в том числе в различиях в социально-политической ориентации (например, «за майдан» или «против майдана», «прозападной» или «пророссийской» ориентации).

Требование полной независимости и отделения от украинского государства обосновывается сторонниками данной позиции также социально-экономическими соображениями. Ограничения на перемещение товаров и передвижение людей, отсутствие доступа к экономическим возможностям по другую сторону линии соприкос- 
новения, а также эмбарго в отношении неподконтрольных районов - все это создает неблагоприятные перспективы для местного развития и сотрудничества в будущем. Такое восприятие подпитывает веру в то, что независимость или объединение с Россией - единственные жизнеспособные варианты. Эти опасения также непосредственно связаны с потребностью в безопасности и возможностью вести достойный образ жизни.

Как и в случае с «жесткой реинтеграцией», одной из причин жесткой позиции, требующей «независимости или объединения с Россией», является, по-видимому, отсутствие прозрачности и адекватной информации о «Минском процессе» и его содержании. Прозрачная и надежная коммуникационная стратегия послужила бы интересам всех заинтересованных сторон ${ }^{265}$.

Позиция 5: «Временная автономия и мягкая независимость»

«Если там будет мирная жизнь, пройдет там пять-десять лет, то сам вопрос особого статуса со временем отпадет». (Центральная Украина)

На другом краю спектра в рамках нарратива «сначала статус» находятся сторонники «временной автономии», которые также рассматривают предоставление неподконтрольным районам автономного статуса как важный первый шаг на пути к миру. Однако в отличие от сторонников «полной независимости или объединения с Россией» они рассматривают данный вопрос с точки зрения национальных интересов Украины. Респондентов, принадлежащих к этой группе, можно назвать умеренными в том смысле, что они согласны с тем, что война и шестилетнее отчуждение между контролируемыми властями и неподконтрольными районами создали новую реальность, которую необходимо учитывать в процессе урегулирования. Но вместо того, чтобы рассматривать автономный статус как окончательное решение, они понимают его как временный компромисс, который позволит Украине «не потерять Донбасс». Временная автономия в сочетании с восстановлением украинской государственности в неподконтрольных районах воспринимается этими респондентами как один из наиболее перспективных вариантов восстановления мира.

\section{Общие интересы: позитивное присутствие украинского государства, удовлетворяющего потребности людей}

В качестве предварительного вывода очевидно, что некоторые из перечисленных выше подходов могут сформировать пространство совпадающих интересов. Идея «мягкой независимости» (позиция 5) представлена в мнениях респондентов из всех областей Украины. Как и в случае с «мягкой реинтеграцией», - это умеренная позиция, исходящая из возможности урегулирования конфликта на основе позитивного присутствия украинского государства, конечной целью которого было бы удовле- 
творение потребностей людей и обеспечение национальных интересов, а также противодействие усилившейся русификации Донбасса.

Хотя подход, предполагающий «временную автономию и мягкую независимость», наиболее ярко проявился в ответах респондентов в контролируемых властями районах, он, по-видимому, совместим и с интересами населения неподконтрольных районов. Значительная часть респондентов в неподконтрольных районах не была категорически против того, чтобы их территория оставалась (или вновь вошла) в составе Украины, но, опасаясь украинских репрессий, выступала прежде всего против «жесткой реинтеграции».

\section{Синтез совпадающих интересов и рекомендации}

Наш краткий анализ двух ключевых нарративов по вопросу восстановления украинской государственности выявил совпадающие интересы, которые могут составить основу для потенциального диалога. За большинством подходов к урегулированию стоят интересы, связанные с выживанием, безопасностью, социально-экономическим благосостоянием и достойным уровнем жизни. Ниже мы предлагаем рекомендации для соответствующих целевых групп по решению выявленных нами общих проблем. Разработка более конкретных мер выходит за рамки данной статьи и должна быть предметом дальнейшего обсуждения всеми сторонами, которые попрежнему привержены мирному урегулированию конфликта на востоке Украины.

\section{1) Безопасность и выживание}

Респонденты всех групп назвали безопасность и прекращение вооруженного насилия основными условиями своего существования, выживания государства и восстановления мира в целом. Жесткие и эмоционально заряженные требования «жесткой реинтеграции» и «независимости любой ценой», как представляется, основываются на глубоком чувстве незащищенности и экзистенциальной угрозы. Переговоры и решения о восстановлении украинской государственности в неподконтрольных властям районах должны учитывать эту неуверенность и опасения, если мы хотим, чтобы соглашение о восстановлении украинской государственности в неподконтрольных районах стало возможным и чтобы его реализация была осуществима. 


\section{Рекомендации}

а) правительству Украинь

- $\quad$ разработать меры по облегчению реинтеграции жителей неподконтрольных районов и возвращающихся донбасских беженцев, например, путем предоставления гарантий того, что жители неподконтрольных районов не будут подвергаться дискриминации в Украине.

b) российскому правительству и фактическим властям неподконтрольных районов

- способствовать демилитаризации и разминированию в неподконтрольных районах.

\section{2) Восстановление «позитивной» украинской государственности}

Еще одной сферой общих интересов, проявившихся в основном в изложенных выше умеренных подходах, является восстановление «позитивного» присутствия украинского государства на Донбассе в целом, основанного на уважении прав и удовлетворении потребностей жителей как неподконтрольных, так и контролируемых властями районов. Примечательно, что респонденты из контролируемых правительством приграничных зон, из не контролируемых властями районов и из России отметили необходимость поиска прагматичных решений проблем, связанных с социальноэкономическим развитием, восстановлением инфраструктуры и трансграничной мобильностью. Многие респонденты из неподконтрольных районов (как в Луганской, так и в Донецкой областях) проявили готовность рассмотреть вариант «мягкой реинтеграции» на основе автономного статуса в сочетании с позитивным присутствием украинского государства. Несколько респондентов из разных групп заявили, что умеренный подход «мягкой интеграции» в сочетании с предоставлением временной автономии или «мягкой независимости» отвечает общим интересов и может быть предметом дальнейшего рассмотрения.

\section{Рекомендации}

а) правительству Украиньь

- разработать комплексную и последовательную стратегию государственного строительства и развития в неподконтрольных районах, чтобы завоевать доверие и поддержку местного населения и облегчить реинтеграцию. 
- $\quad$ разработать простой, безопасный и прозрачный режим перемещения между неподконтрольными и контролируемыми властями районами через контрольно-пропускные пункты на линии соприкосновения.

b) ОБСЕ, украинскому правительству и организациям гражданского общества

- разработать механизмы сотрудничества между ОБСЕ и Министерством по вопросам реинтеграции временно оккупированных территорий Украины, с одной стороны, и организациями гражданского общества, обладающими опытом в области осуществления правосудия переходного периода, инициатив по развитию диалога и местного развития в неподконтрольных районах - с другой.

с) российскому правительству и фактическим властям неподконтрольных районов

- поддерживать свободное передвижение украинских граждан путем содействия простому, безопасному и прозрачному режиму пересечения линии соприкосновения, в частности, за счет возобновления работы существующих и открытия дополнительных контрольно-пропускных пунктов в Луганской области (в Счастье и Золотом).

\section{3) Прозрачность и коммуникация}

Несколько респондентов в контролируемых властями и в неподконтрольных районах, а также из числа донбасских беженцев и в России указали, что тот небольшой объем информации, который у них есть, о содержании и развитии «Минского процесса», поступает из неформальных источников.

\section{Рекомендации}

а) ОБСЕ, а также правительствам Украины и России

- разработать механизмы систематической и регулярной коммуникации для передачи и обсуждения информации о «Минском процессе», его содержательной стороне, о ходе переговоров, а также о работе Трехсторонней контактной группы с широкой общественностью, включая украинскую, российскую и международную аудиторию.

b) правительству Украинь

- открыто и прозрачно информировать о временном характере особого статуса и автономии неподконтрольных районов, как это предусмотрено в рамках «Минского процесса». Это будет способствовать снижению напряженности и поляризации общества, причем реализация малых и временных мер пред- 
ставляет собой более реалистичный подход, чем попытки договориться об «одном большом решении».

с) правительству России и фактическим властям неподконтрольных районов

- содействовать формированию в неподконтрольных районах открытого коммуникационного пространства для украинских и международных средств массовой информации (включая доступ к трансляции украинских и международных программ в цифровом, аналоговом и кабельном форматах).

\section{Примечания}

251 Пользуясь случаем, мы хотели бы поблагодарить внешних рецензентов, чьи тонкие и полезные комментарии помогли внести последние штрихи в эту статью.

252 Члены исследовательской группы работают в различных географических регионах, затронутых конфликтом. Авторы данной статьи входили в состав исследовательской группы и являются участниками диалоговой платформы ЖИМД.

253 «Женские инициативы за мир на Донбассе» (ЖИМД) - это платформа для диалога и сотрудничества по вопросам, связанным с конфликтом на востоке Украины, объединяющая женщин в Украине, в том числе в районах, не контролируемых правительством, России и Западной Европе. Для получения более подробной информации о ЖИМД см.: Jirouš D. Red lights and diapraxis // FriEnt Website, TJ Blog. 2019. 15 November. URL:

https://www.frient.de/en/blogdata/tj-blog/red-lights-and-diapraxis?fbclid=IwAR03ALYQC59_5 VNxMpo0UV6VYAaYONdlWwOqbVQU1FR65YsnRrvEI6OhevY.

254 Помимо концептуальной поддержки ЖИМД обеспечила доступ к респондентам всех конфликтующих сторон, помогая обеспечить инклюзивный характер наших исследований. Исследовательская группа также получила концептуальную, финансовую и методологическую поддержку Центра культуры и управления в Европе при университете Сен-Галлена (Швейцария), программы «Украина зовет», Фонда Роберта Боша и Федерального министерства иностранных дел Германии. Мы хотели бы выразить искреннюю благодарность за эту поддержку.

255 Описание истоков понятия «диапрактики» см.: Bitter J.-N. Diapraxis in Different Contexts: A Brief Discussion with Rasmussen // Politorbis. - 2011. - No 2. - P. 65-69.

256 Фишер Р., Юри У., Паттон Б. Переговоры без поражения. Гарвардский метод / пер. с англ. Татьяны Новиковой. - 3-е изд. - М.: Манн, Иванов и Фербер, 2014.

257 Информацию о точном количестве и происхождении погибших и раненых в 2014-2020 гг. можно найти на сайте Управления Верховного комиссара ООН по правам человека: Report on the human rights situation in Ukraine: 16 November 2019 to 15 February 2020 // Office of the United Nations High Commissioner for Human Rights, February 2020. URL: https: //www.ohchr.org/Documents/Countries/UA/29thReportUkraine_EN.pdf.

258 По данным Единой информационной базы данных о внутренне перемещенных лицах Министерства социальной политики Украины, по состоянию на 12 мая 2020 года было зарегистрировано 1446651 внутренне перемещенное лицо из неподконтрольных правительству районов Донецкой и Луганской областей и Автономной Республики Крым. См. официальный сайт Министерства социальной политики Украины. 2020. 12 мая. URL: https://w ww.msp.gov.ua/news/18640.html. 
259 Литвинова М. Мама посадила в поезд в Белгород, а на следующий день в здание вокзала попал снаряд // Коммерсантъ. - 2020. - 18 апреля. URL: https://www.kommersant.ru/doc/432 3849 .

260 Ukraine crisis in maps // BBC News. 2015. 18 February. URL: https://www.bbc.com/news/worl d-europe-27308526.

261 Последние также называются «Отдельные районы Донецкой и Луганской областей» (ОРДЛО).

262 Подробнее см.: Протокол по итогам консультаций Трехсторонней контактной группы относительно совместных шагов, направленных на имплементацию Мирного плана Президента Украины П. Порошенко и инициатив Президента России В. Путина, 5 сентября 2014 г. // Официальный сайт ОБСЕ. URL: https://www.osce.org/files/f/documents/a/a/123258.pdf; Комплекс мер по выполнению Минских договоренностей, 12 февраля 2015 г. // Официальный сайт ОБСЕ. URL: https://www.osce.org/files/f/documents/5/b/140221.pdf. См. также: The security and human rights special issue on OSCE mediation and conflict management / A. Hess Sargsyan (ed.) // Security and Human Rights Monitor. - November 2017. URL: https://www.shr monitor.org/security-human-rights-special-issue-osces-mediation-conflict-management-introduct ion-conclusion/; Hess Sargsyan A. Unpacking complexity in the Ukraine peace process. CSS Analyses in Security Policy Nr. 243 / B. Zogg (ed.). April 2019. URL: https://css.ethz.ch/content /dam/ethz/special-interest/gess/cis/center-for-securities-studies/pdfs/CSSAnalyse243-EN.pdf.

263 О внутриукраинской дискуссии вокруг особого статуса см.: Ukrainian lawmakers extend Donbas special status law until end of 2020 // Radio Free Europe/Radio Liberty Ukrainian Service. 2019. 12 December. URL: https://www.rferl.org/a/ukrainian-lawmakers-extend-donbas-spe cial-status-law-until-end-of-2020/30321863.html

264 Galtung J. Essays in Peace Research I - Peace: Research. Education. Action. - Copenhagen: Ejlers, 1975.

265 Позитивным примером в этом отношении является блог на сайте Администрации Президента Украины о текущей деятельности в рамках Минского процесса. См.: Заседание ТКГ // Официальный сайт Президента Украины. 2020. 14 октября. URL: https://www.presid ent.gov.ua/ru/news/zasidannya-tkg-obsye-vidznachila-stalij-rezhim-tishi-vprodov-64589. 
